Article

\title{
A Novel Fluorescent Probe for Hydrogen Peroxide and Its Application in Bio-Imaging
}

\author{
Yingying Zuo, Yang Jiao*(D), Chunming Ma and Chunying Duan \\ State Key Laboratory of Fine Chemicals, Dalian University of Technology, Dalian 116024, China; \\ z943877035@mail.dlut.edu.cn (Y.Z.); sxcm98@gmail.com (C.M.); cyduan@dlut.edu.cn (C.D.) \\ * Correspondence: jiaoyang@dlut.edu.cn
}

Citation: Zuo, Y.; Jiao, Y.; Ma, C.; Duan, C. A Novel Fluorescent Probe for Hydrogen Peroxide and Its Application in Bio-Imaging. Molecules 2021, 26, 3352. https://doi.org/ $10.3390 /$ molecules 26113352

Academic Editor: Mei Pan

Received: 1 May 2021

Accepted: 28 May 2021

Published: 2 June 2021

Publisher's Note: MDPI stays neutral with regard to jurisdictional claims in published maps and institutional affiliations.

Copyright: (c) 2021 by the authors. Licensee MDPI, Basel, Switzerland. This article is an open access article distributed under the terms and conditions of the Creative Commons Attribution (CC BY) license (https:// creativecommons.org/licenses/by/ $4.0 /)$.
Abstract: Hydrogen peroxide $\left(\mathrm{H}_{2} \mathrm{O}_{2}\right)$ plays an important role in the human body and monitoring its level is meaningful due to the relationship between its level and diseases. A fluorescent sensor (CMB) based on coumarin was designed and its ability for detecting hydrogen peroxide by fluorescence signals was also studied. The CMB showed an approximate 25 -fold fluorescence enhancement after adding $\mathrm{H}_{2} \mathrm{O}_{2}$ due to the interaction between the $\mathbf{C M B}$ and $\mathrm{H}_{2} \mathrm{O}_{2}$ and had the potential for detecting physiological $\mathrm{H}_{2} \mathrm{O}_{2}$. It also showed good biocompatibility and permeability, allowing it to penetrate cell membranes and zebrafish tissues, thus it can perform fluorescence imaging of $\mathrm{H}_{2} \mathrm{O}_{2}$ in living cells and zebrafish. This probe is a promising tool for monitoring the level of $\mathrm{H}_{2} \mathrm{O}_{2}$ in related physiological and pathological research.

Keywords: hydrogen peroxide; reactive oxygen species; fluorescence; imaging

\section{Introduction}

Reactive oxygen species (ROS) play important roles in a wide variety of biological functions [1,2], and its abnormal production or accumulation is also closely related to many physiological and pathological processes [3,4], especially, the concentration of ROS in cancer cells is much higher than that in normal cells. Hydrogen peroxide $\left(\mathrm{H}_{2} \mathrm{O}_{2}\right)$, the least reactive and mildest oxidant among reactive oxygen species [5], can regulate many physiological processes in organisms and even affect the growth and development of cell [6-8]. It is produced in low levels during the metabolism of normal living cells and excessive $\mathrm{H}_{2} \mathrm{O}_{2}$ production or accumulation in vivo is also considered as the key contributor to many diseases [9-11]. $\mathrm{H}_{2} \mathrm{O}_{2}$ is overproduced when there is an exogenous stimulus or the content of antioxidants is severely reduced, which may be found in numerous diseases, such as cardiovascular disease and cancer [12-14]. Thus, it is significant to find a method that can detect and quantify the production of $\mathrm{H}_{2} \mathrm{O}_{2}$ to facilitate the diagnosis and treatment of diseases.

In recent years, various analytical methods that can detect hydrogen peroxide have been reported, such as fluorescence spectroscopy, electroanalysis, chemiluminescence, etc. [15]. The fluorescence detection method is paid much attention among many other analytical methods due to its characteristics of good selectivity, high sensitivity, quick response rate, as well as real-time detection [16-18]. It tends to be used for detecting and tracking certain biomolecules in cells or organisms [19] because of its non-invasiveness and ease of operation [20-22], and thus has great potential in detecting small molecules' markers to help in the diagnosis of some diseases. Some fluorescent small-molecule probes for detecting ROS have been reported [23-27]. These studies proved the feasibility of using fluorescent small-molecule probes to detect $\mathrm{H}_{2} \mathrm{O}_{2}$ and can promote the development and progress of $\mathrm{H}_{2} \mathrm{O}_{2}$ probes, which may facilitate the realization of its applications in medicine.

Herein, a smart small-molecule fluorescent probe, CMB, was designed and synthesized for $\mathrm{H}_{2} \mathrm{O}_{2}$ imaging in solution, cells, and zebrafish by employing coumarin as fluorophore and the boronate as the recognition group [28-30] (Scheme 1). A short alkyl 
chain is used to connect the morpholine group with coumarin to improve the biological applicability of the probe. The fluorescence signal of $\mathbf{C M B}$ would be enhanced in the presence of $\mathrm{H}_{2} \mathrm{O}_{2}$ due to the reaction between probe $\mathrm{CMB}$ and $\mathrm{H}_{2} \mathrm{O}_{2}$, and the good linear relationship between the fluorescence intensity and the concentration of $\mathrm{H}_{2} \mathrm{O}_{2}$ also facilitates its detection. Probe $\mathbf{C M B}$ can not only shows enhanced fluorescence signal to $\mathrm{H}_{2} \mathrm{O}_{2}$ with good selectivity, but also exhibits desirable imaging effects on $\mathrm{H}_{2} \mathrm{O}_{2}$ in cells and zebrafish, which indicates that CMB has the potential to monitor the content and level of hydrogen peroxide in biological systems.

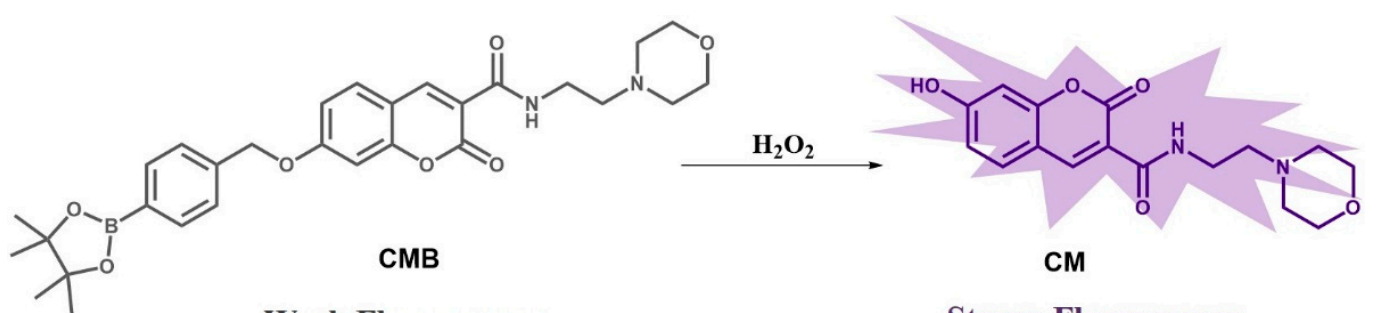

Weak Fluorescence

Strong Fluorescence

Scheme 1. The mechanism of CMB to detect $\mathrm{H}_{2} \mathrm{O}_{2}$.

\section{Results and Discussion}

\subsection{Design Strategy of Probe CMB}

The probe $\mathbf{C M B}$ was designed and synthesized in three steps from the coumarin moiety (Scheme 2) that possesses excellent photo-physical properties [31,32]. The morpholine group can increase the solubility of the probe in water, thereby increasing biocompatibility and making it more beneficial for imaging in biological environments. The aryl boronate can be bound to the hydroxyl group of $\mathbf{C M}$ by the ether linkage strategy to form CMB and react with $\mathrm{H}_{2} \mathrm{O}_{2}$ as well as providing the specificity for $\mathrm{H}_{2} \mathrm{O}_{2}$ over other interference species $[33,34]$. The synthetic route of probe $\mathbf{C M B}$ was provided and shown in Scheme 2. The structure of CMB was accurately validated using the ${ }^{1} \mathrm{H}$ NMR and HRMS analyses presented in the Supporting Information (Supplementary Figures S1-S4).

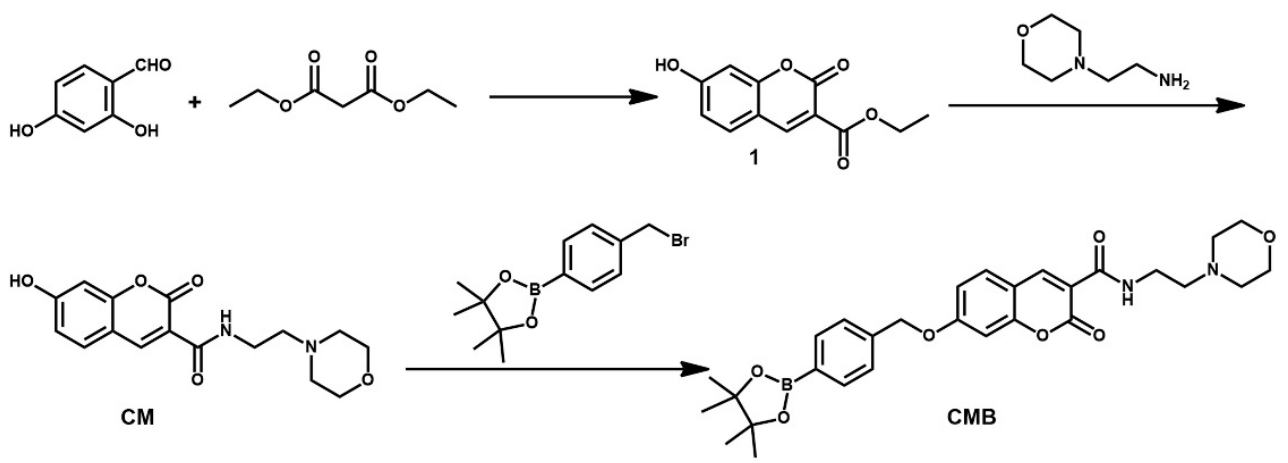

Scheme 2. The synthesis route of probe CMB.

\subsection{Optical Response of $\mathbf{C M B}$ to $\mathrm{H}_{2} \mathrm{O}_{2}$}

The UV-vis absorption and fluorescence emission spectra were both studied in acetonitrile/phosphate buffer $(1: 9 v / v, 10 \mathrm{mM}, \mathrm{pH} 7.4)$ at room temperature to test the optical properties of CMB in the presence or absence of $\mathrm{H}_{2} \mathrm{O}_{2}$. The UV-vis spectrum of the probe CMB $(6 \mu \mathrm{M})$ showed a absorption band at $350 \mathrm{~nm}$, then a new band appeared at $405 \mathrm{~nm}$ after being treated with $\mathrm{H}_{2} \mathrm{O}_{2}$ (Figure 1a), which may be attributed to the chemical structure change from CMB to CM. As shown in Figure 1b, CMB had only a very weak fluorescence when excited at $400 \mathrm{~nm}$, while a significant increase in fluorescence was observed at $450 \mathrm{~nm}$ after adding $\mathrm{H}_{2} \mathrm{O}_{2}$. With the increase of hydrogen peroxide concentration, the fluorescence intensity of CMB increased by about 25-fold (Figure 1c). There is a good linear relationship 
between the fluorescence intensity and the concentration of $\mathrm{H}_{2} \mathrm{O}_{2}$ in the range of 0 to $50 \mu \mathrm{M}$ with a correlation coefficient of 0.9979 (Figure $1 \mathrm{~d}$ ) and the detection limit was $0.13 \mu \mathrm{M}$, thus being able to be used for direct imaging of physiological $\mathrm{H}_{2} \mathrm{O}_{2}$ [23]. This fluorescence change may be attributed to the structural change from $\mathbf{C M B}$ to $\mathbf{C M}$ caused by the reaction with $\mathrm{H}_{2} \mathrm{O}_{2}$. The good "off-on" response of CMB toward $\mathrm{H}_{2} \mathrm{O}_{2}$ showed its potential for detection of $\mathrm{H}_{2} \mathrm{O}_{2}$ and may realize the detection of $\mathrm{H}_{2} \mathrm{O}_{2}$ level.
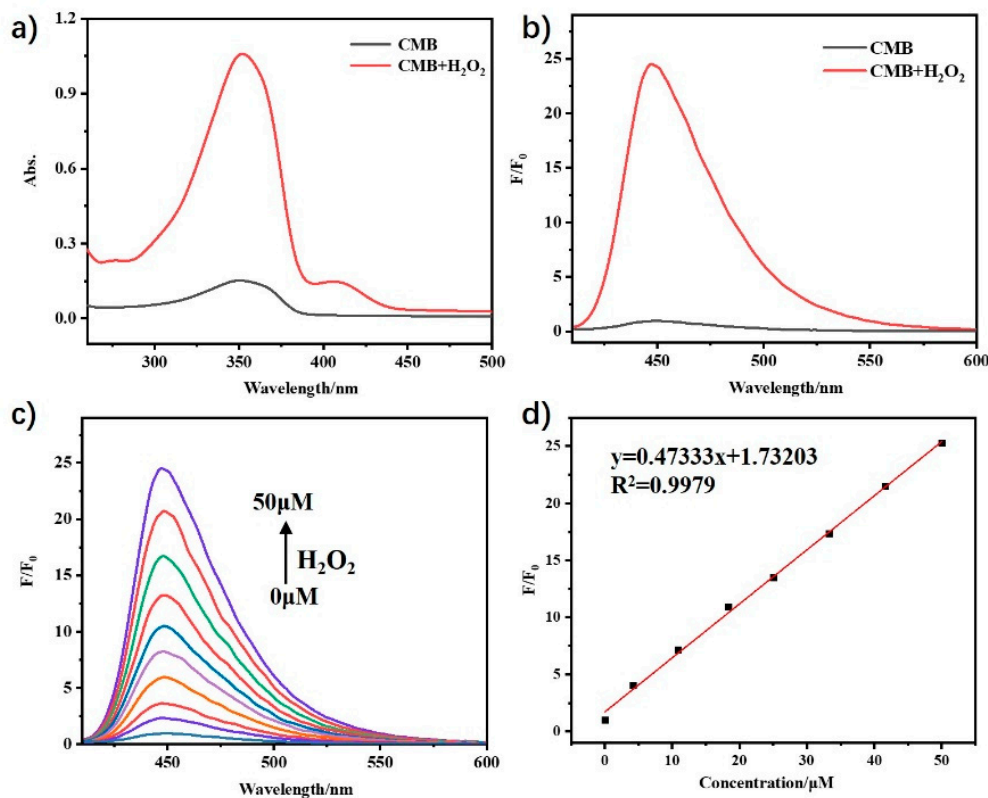

Figure 1. (a) UV-vis absorption and (b) fluorescence emission spectra of CMB before and after addition of $\mathrm{H}_{2} \mathrm{O}_{2}$. (c) Fluorescence responses of $\mathbf{C M B}(2 \mu \mathrm{M})$ to various concentrations of $\mathrm{H}_{2} \mathrm{O}_{2}$. (d) The linear correlation between the fluorescence intensity at $450 \mathrm{~nm}$ and $\mathrm{H}_{2} \mathrm{O}_{2}$ concentration.

The response time of probe $\mathrm{CMB}$ toward $\mathrm{H}_{2} \mathrm{O}_{2}$ was also investigated by the timedependent fluorescence intensity. After adding $\mathrm{H}_{2} \mathrm{O}_{2}$ to the solution of probe $\mathrm{CMB}$, the fluorescence intensity at $450 \mathrm{~nm}$ gradually increased with time and stabilized finally. The selectivity study of probe CMB was carried out in the presence of various biologically relevant possible competing species, mainly including ions $\left(\mathrm{K}^{+}, \mathrm{Mg}^{2+}, \mathrm{Fe}^{3+}, \mathrm{Cl}^{-}\right.$, etc.), amino acids (Cys, Pro), reactive oxygen species $\left(\bullet \mathrm{OH}, \mathrm{TBHP}, \mathrm{ClO}^{-}\right.$, etc. $)[35,36]$. As shown in Figure $2 b$, ions, amino acids, and most of the reactive oxygen species showed negligible changes in fluorescence and ${ }^{1} \mathrm{O}_{2}$ and $\mathrm{NO}_{2}{ }^{-}$caused a slight response. The fluorescence enhancement of $\mathbf{C M B}$ to $\mathrm{H}_{2} \mathrm{O}_{2}$ is more obvious relative to the interferences. In order to further verify the specific reaction between the probe and $\mathrm{H}_{2} \mathrm{O}_{2}$, the catalase (hydrogen peroxide quencher) and glucose oxidase (hydrogen peroxide producer) were used to perform the fluorescence experiment. When $\mathrm{H}_{2} \mathrm{O}_{2}$ is treated with catalase, $\mathbf{C M B}$ no longer produced a significant increase in fluorescence toward it, but when glucose reacted with glucose oxidase was added, the obvious fluorescence enhancement was observed due to the $\mathrm{H}_{2} \mathrm{O}_{2}$ produced by the reaction, which proved the specificity of $\mathbf{C M B}$ to $\mathrm{H}_{2} \mathrm{O}_{2}$. The obvious fluorescence response and extended linear range as well as good biocompatibility and permeability make CMB an excellent candidate and can serve as the indicators for $\mathrm{H}_{2} \mathrm{O}_{2}$ detection compared with other candidates (Supplementary Table S1). All the results illustrated that $\mathbf{C M B}$ can react with hydrogen peroxide selectively to achieve fluorescence enhancement and we hope that it is suitable in a bio-environment. 

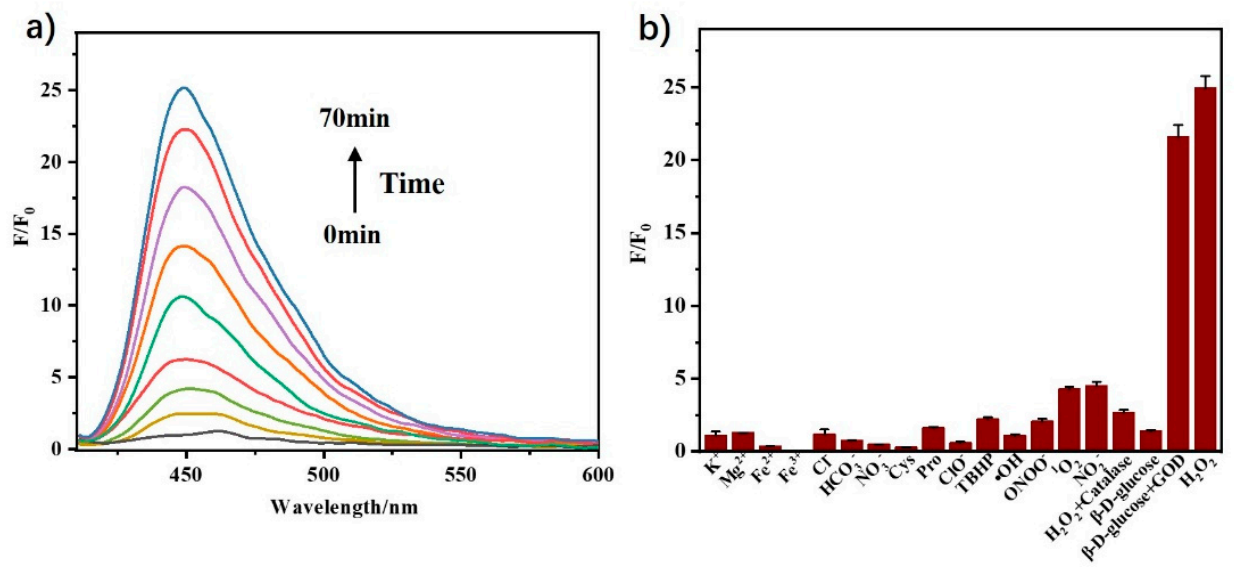

Figure 2. (a) The time response of the probe CMB. (b) Fluorescence response of $\mathbf{C M B}(2 \mu \mathrm{M})$ to various competing species $(100 \mu \mathrm{M})$, including $\mathrm{K}^{+}, \mathrm{Mg}^{2+}, \mathrm{Fe}^{2+}, \mathrm{Fe}^{3+}, \mathrm{Cl}^{-}, \mathrm{HCO}_{3}^{-}, \mathrm{NO}_{3}{ }^{-}$, cysteine (Cys), proline (Pro), hypochlorite $\left(\mathrm{ClO}^{-}\right)$, tert-butyl hydroperoxide (TBHP), hydroxyl radical $(\bullet \mathrm{OH})$, peroxynitrite $\left(\mathrm{ONOO}^{-}\right)$, singlet oxygen $\left({ }^{1} \mathrm{O}_{2}\right)$, nitrite $\left(\mathrm{NO}_{2}{ }^{-}\right), \mathrm{H}_{2} \mathrm{O}_{2}+$ catalase, $\beta$-D-glucose, $\beta$-Dglucose + glucose oxidase (GOD), and $\mathrm{H}_{2} \mathrm{O}_{2}$.

\subsection{Response Mechanism of $\mathbf{C M B}$ to $\mathrm{H}_{2} \mathrm{O}_{2}$}

According to the fluorescence response of $\mathbf{C M B}$ to $\mathrm{H}_{2} \mathrm{O}_{2}$, the possible response mechanism of $\mathrm{H}_{2} \mathrm{O}_{2}$ detection can be preliminarily assumed (Scheme 1). When the fluorophore was connected with the aryl boronate, $\mathbf{C M B}$ showed almost no fluorescence due to the intramolecular interaction. The added $\mathrm{H}_{2} \mathrm{O}_{2}$ will react with the aryl boronate group, causing the hydroxyl of the fluorophore to be released, thereby revealing a strong fluorescent signal. In order to confirm the mechanism, high-resolution mass spectrometry (HRMS) was performed. CMB showed an intense peak at $m / z=535.2606$ (Supplementary Figure S4). After adding $\mathrm{H}_{2} \mathrm{O}_{2}$, the peak of CMB had almost disappeared, while a new peak at $\mathrm{m} / \mathrm{z}=$ 319.1291 appeared accompanied by the peak of the intermediate product at $m / z=425.1710$, proving the transformation of $\mathrm{CMB}$ into $\mathrm{CM}$ by the reaction of aryl boronate group and $\mathrm{H}_{2} \mathrm{O}_{2}$. The liquid chromatography experiments were also done. As shown in Figure $3 b$, the $\mathrm{CMB}$ had a signal peak at $20.528 \mathrm{~min}$. After adding $\mathrm{H}_{2} \mathrm{O}_{2}$, a new peak appeared at $9.116 \mathrm{~min}$, which had the same as the retention time of $\mathbf{C M}$. Thus, the experiments both supported the fact that the structural transformation caused by the reaction of CMB with $\mathrm{H}_{2} \mathrm{O}_{2}$ triggers the enhanced fluorescence signal, proving our inference about the response mechanism of $\mathbf{C M B}$ to $\mathrm{H}_{2} \mathrm{O}_{2}$ proposed in Scheme 1 .

\subsection{Cytotoxicity and Fluorescence Imaging in Living Cells}

Taking into account the particularity of the biological environment, the viability of cells against the probe was determined using the CCK8 assay technique [37] to evaluate the cytotoxicity of the CMB. The relative growth rate of cells was detected upon exposure to CMB with concentrations of 0 to $20 \mu \mathrm{M}$ for $24 \mathrm{~h}$. As is shown in Figure 4, the cell survival rate was greater than $90 \%$ at probe concentrations up to $20 \mu \mathrm{M}$, demonstrating that $\mathrm{CMB}$ has an acceptable cytotoxicity to cells within this concentration range and can be used in biological systems. Thus, it can perform the subsequent cell imaging experiment. 

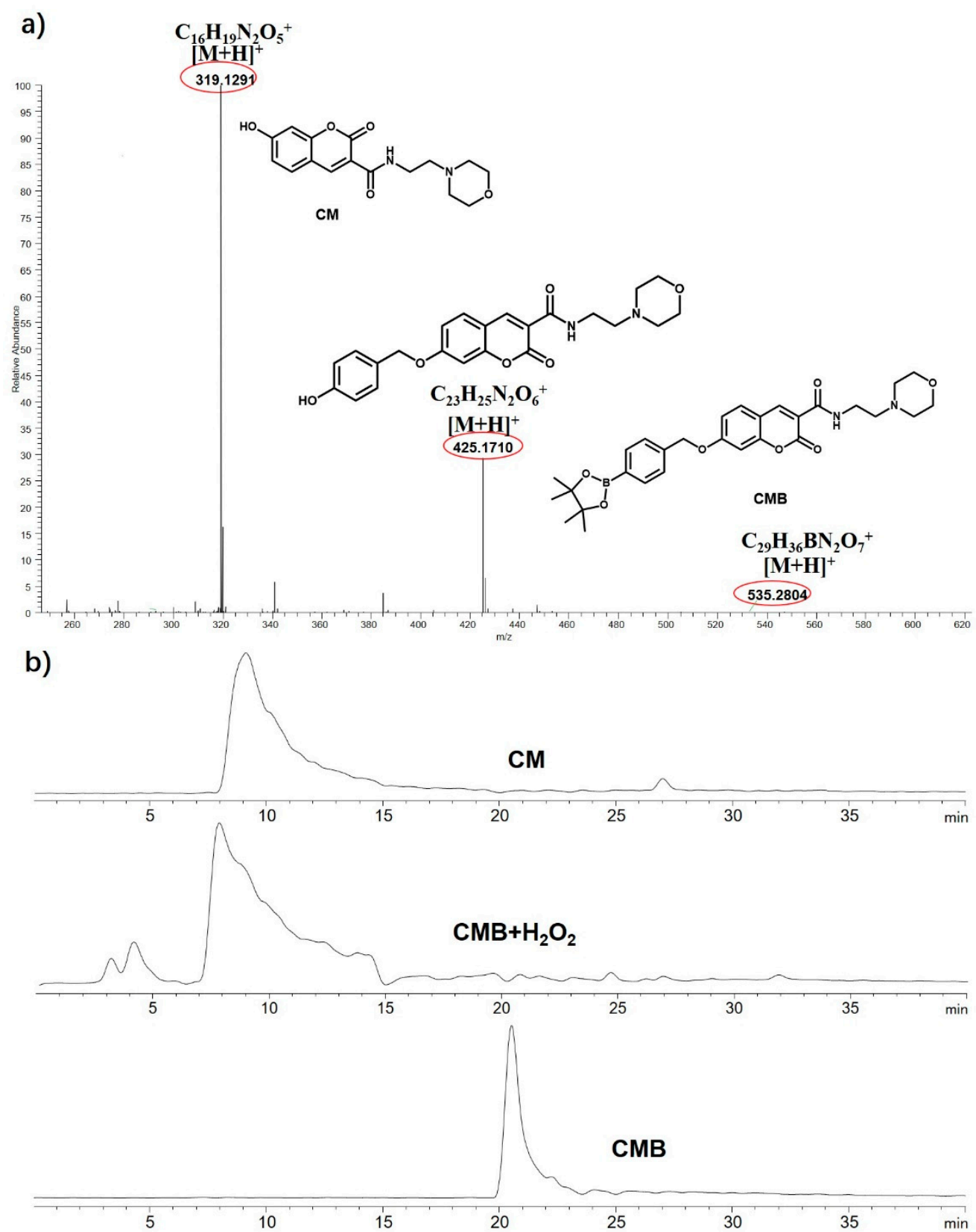

Figure 3. (a) HRMS of CMB after adding $\mathrm{H}_{2} \mathrm{O}_{2}$. (b) Liquid chromatography of $\mathbf{C M B}, \mathbf{C M B}$ treated with $\mathrm{H}_{2} \mathrm{O}_{2}$, and $\mathbf{C M}$.

Then, we carried out the imaging experiment to test the practical feasibility of $\mathrm{CMB}$ for exogenous and endogenous $\mathrm{H}_{2} \mathrm{O}_{2}$ detection. When MCF-7 cells were stained with CMB alone, there was almost no fluorescence, but was observed that the fluorescence signal increased significantly and dose-dependently after treating cells with different concentrations of $\mathrm{H}_{2} \mathrm{O}_{2}(0$ to $50 \mu \mathrm{M})$ (Figure $5 \mathrm{a}$ ), which also proved that the CMB could effectively penetrate the cell membrane and disperse in the cytoplasm. In addition, the cells were incubated with $\mathrm{H}_{2} \mathrm{O}_{2}$ and then treated with $\mathrm{CMB}$ for imaging at different time points. It was found that the fluorescence intensity gradually increased over time (Figure $5 b$ ), which further indicates that $\mathrm{CMB}$ can be used to detect exogenous $\mathrm{H}_{2} \mathrm{O}_{2}$. 


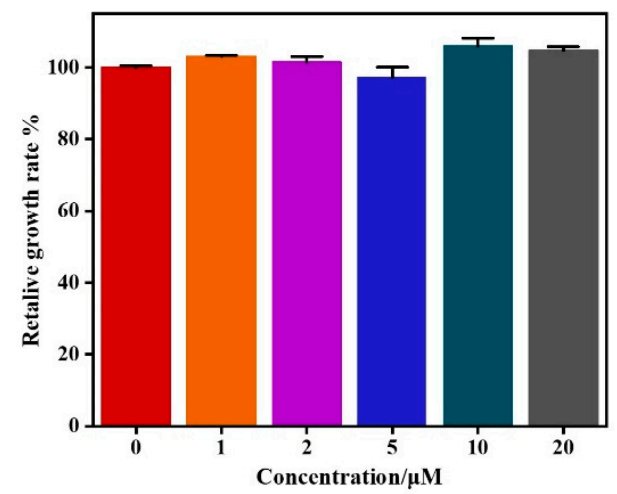

Figure 4. Relative growth rate (\%) of cells that were cultured in the presence of a 0 to $20 \mu \mathrm{M}$ probe CMB for $24 \mathrm{~h}$ and estimated by the CCK8 assay.

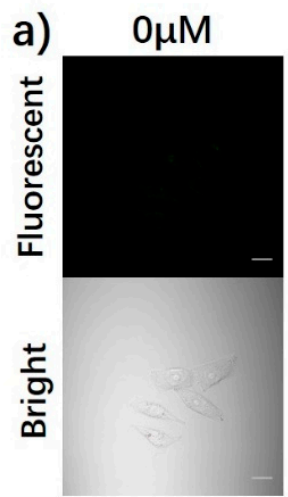

b)

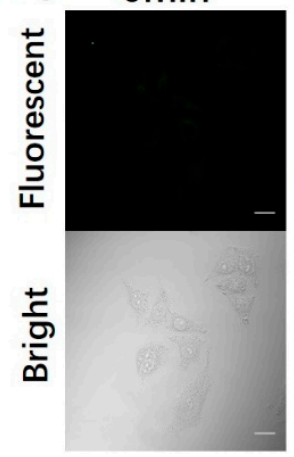

$10 \mu \mathrm{M}$

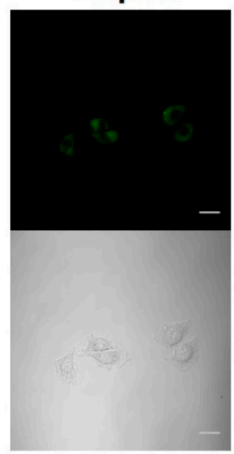

$10 \mathrm{~min}$

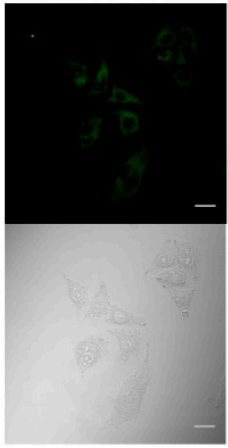

$25 \mu \mathrm{M}$

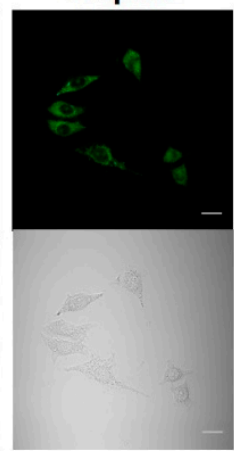

$30 \mathrm{~min}$

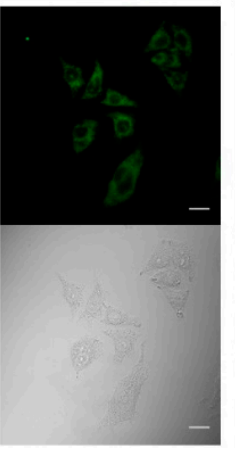

$40 \mu \mathrm{M}$

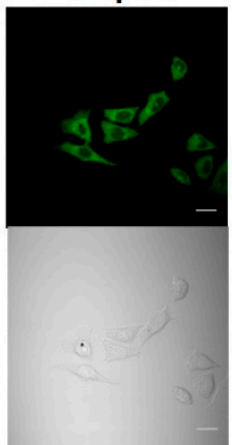

$50 \mathrm{~min}$

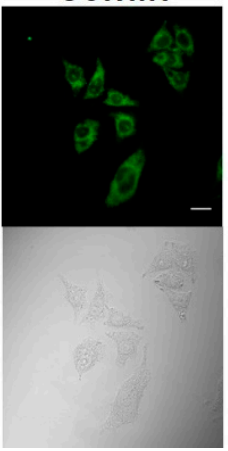

$50 \mu \mathrm{M}$

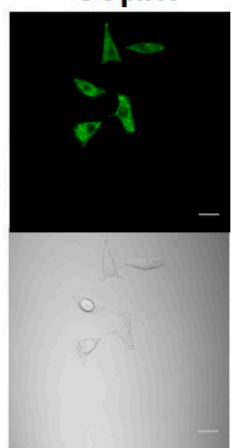

$70 \mathrm{~min}$

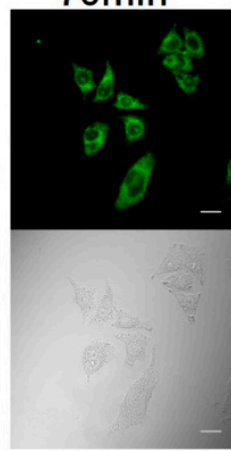

Figure 5. Confocal images after the addition of exogenous $\mathrm{H}_{2} \mathrm{O}_{2}$ in MCF-7 cells. (a) Cells were stained with different concentrations of $\mathrm{H}_{2} \mathrm{O}_{2}$ and then incubated with CMB $(2 \mu \mathrm{M})$. (b) Cells were pretreated with $\mathrm{H}_{2} \mathrm{O}_{2}(50 \mu \mathrm{M})$, and then incubated with $\mathbf{C M B}(2 \mu \mathrm{M})$ at different time points $(0$ to $70 \mathrm{~min})$. The excitation wavelength was $405 \mathrm{~nm}$ and the emission was collected at 420 to $520 \mathrm{~nm}$. Scale bar $=20 \mu \mathrm{m}$.

In addition, endogenous hydrogen peroxide is generated by the stimulation of rotenone [38,39], so the imaging ability of CMB to the endogenous $\mathrm{H}_{2} \mathrm{O}_{2}$ level of MCF-7 cells could be studied by adding rotenone. When cells were treated with rotenone with the addition of $\mathbf{C M B}$, an obvious fluorescence could be observed (Figure 6). After incubating the rotenone-pretreated cells with $\mathrm{N}$-acetylcysteine (NAC) [40], a common $\mathrm{H}_{2} \mathrm{O}_{2}$ inhibitor, the intracellular fluorescence was basically negligible, indicating the $\mathrm{H}_{2} \mathrm{O}_{2}$ produced by the stimulation of rotenone was eliminated. These results proved the ability of $\mathbf{C M B}$ to detect endogenous $\mathrm{H}_{2} \mathrm{O}_{2}$. The cell imaging experiment demonstrated that the $\mathbf{C M B}$ has favorable membrane-permeability, showing its potential for fluorescence imaging of exogenous and endogenous $\mathrm{H}_{2} \mathrm{O}_{2}$ levels in cells. 

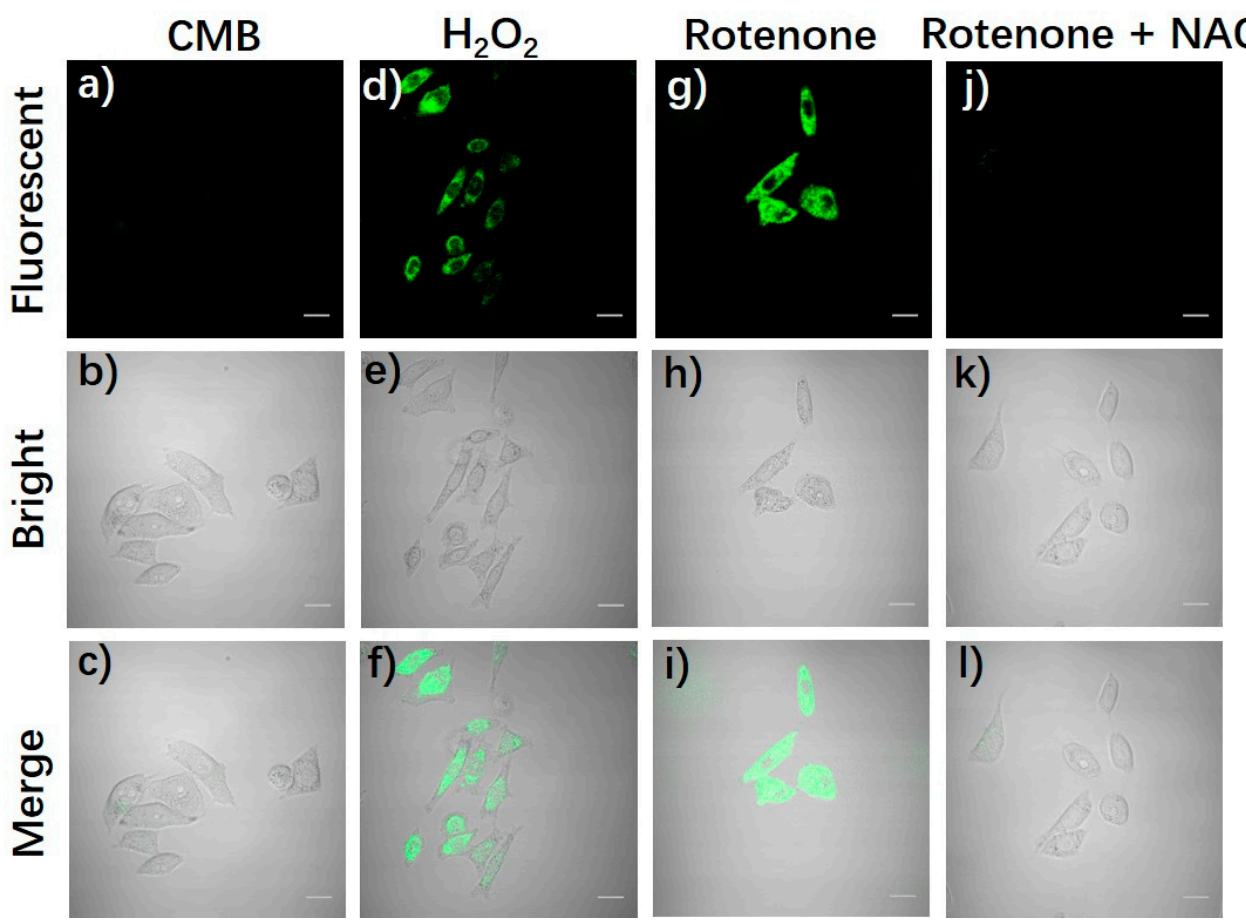

Figure 6. Confocal images for exogenous and endogenous $\mathrm{H}_{2} \mathrm{O}_{2}$ in MCF-7 cells. (a-c) Cells were stained with CMB $(2 \mu \mathrm{M})$. (d-f) Cells were incubated with $\mathrm{H}_{2} \mathrm{O}_{2}$ and then stained with CMB $(2 \mu \mathrm{M})$. (g-i) Cells were incubated with rotenone and then stained with CMB $(2 \mu \mathrm{M})$. (j-1) Cells were incubated with rotenone, treated with NAC, and then stained with CMB $(2 \mu \mathrm{M})$. The excitation wavelength was $405 \mathrm{~nm}$ and the emission was collected at 420 to $520 \mathrm{~nm}$. Scale bar $=20 \mu \mathrm{m}$.

\subsection{Zebrafish Imaging}

To further investigate the availability of the probe CMB in biological systems, a zebrafish imaging experiment was carried out to detect its fluorescence imaging performance. As shown in Figure 7, zebrafish incubated with $\mathrm{H}_{2} \mathrm{O}_{2}$ and then treated with CMB showed obvious fluorescence, while the control group treated only with CMB exhibited negligible fluorescence. Besides, the fluorescence intensity of zebrafish treated with rotenone also increased significantly, and after further treatment with NAC, its weak fluorescence was similar to that of the control group. In addition, the z-scan mode of the confocal microscope was used to record the fluorescence intensity at different depths in the body of the zebrafish to explore the penetration capability of the probe in tissue. As shown in Supplementary Figure S5, bright fluorescence was observed even at a depth of up to $180 \mu \mathrm{m}$, showing the probe $\mathbf{C M B}$ had tissue penetrating and staining capabilities. Thus, $\mathbf{C M B}$ has excellent penetration and exhibits good imaging feasibility for endogenous and exogenous $\mathrm{H}_{2} \mathrm{O}_{2}$ in zebrafish. 


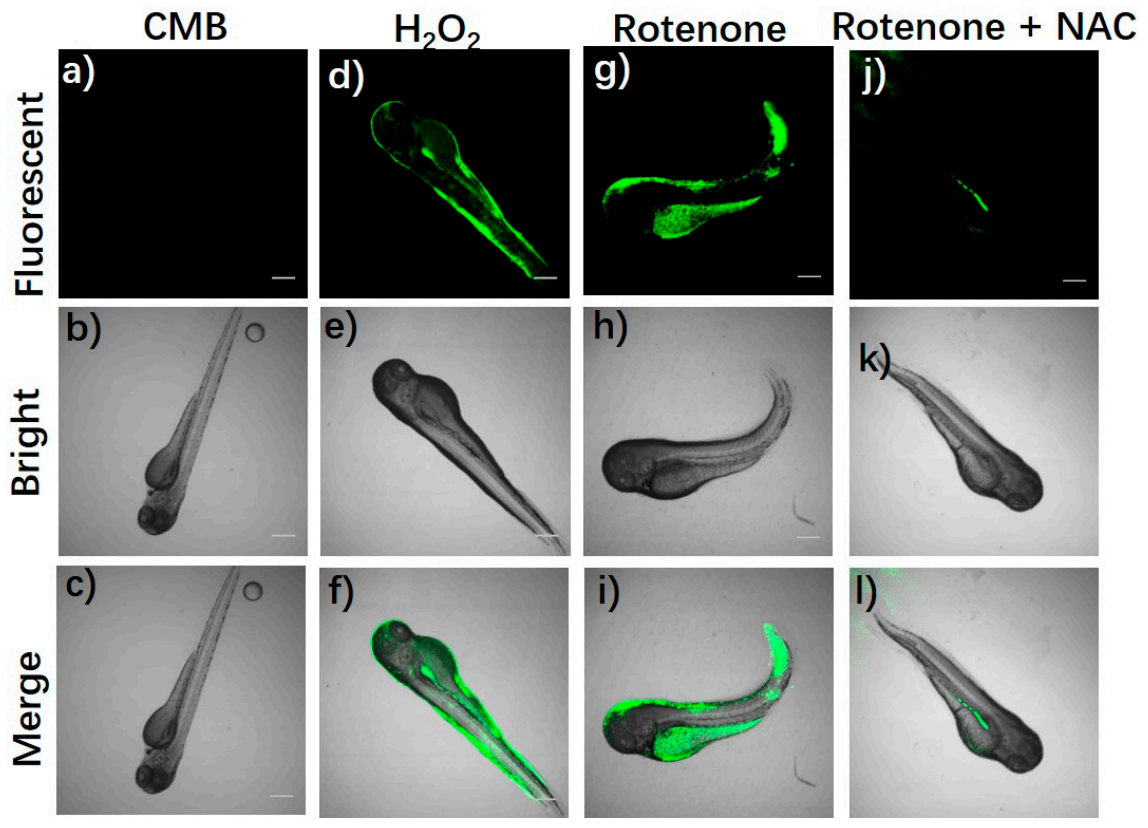

Figure 7. Confocal images for exogenous and endogenous $\mathrm{H}_{2} \mathrm{O}_{2}$ in zebrafish. (a-c) Zebrafish were stained with $\mathbf{C M B}(2 \mu \mathrm{M})$. (d-f) Zebrafish were incubated with $\mathrm{H}_{2} \mathrm{O}_{2}$ and then stained with CMB $(2 \mu \mathrm{M}) .(\mathrm{g}-\mathbf{i})$ Zebrafish were incubated with rotenone and then stained with $\mathbf{C M B}(2 \mu \mathrm{M}) .(\mathbf{j}-\mathbf{l})$ Zebrafish were incubated with rotenone, treated with NAC, and then stained with CMB $(2 \mu \mathrm{M})$. The excitation wavelength was $405 \mathrm{~nm}$ and the emission was collected at 420 to $520 \mathrm{~nm}$. Scale bar = $300 \mu \mathrm{m}$.

\section{Conclusions}

In summary, a novel fluorescence probe CMB based on coumarin was designed and developed successfully, that could interact with $\mathrm{H}_{2} \mathrm{O}_{2}$ and realize its detection by fluorescence. It can react with $\mathrm{H}_{2} \mathrm{O}_{2}$ selectively, thus producing an enhanced fluorescence signal. The probe CMB has low toxicity and good biocompatibility, and it can penetrate the cell membranes and zebrafish tissues to image endogenous and exogenous $\mathrm{H}_{2} \mathrm{O}_{2}$. The good penetration and staining ability further prove the feasibility of CMB to accurately monitor $\mathrm{H}_{2} \mathrm{O}_{2}$ in biological systems. It is expected that CMB will become a promising tool to detect the $\mathrm{H}_{2} \mathrm{O}_{2}$ and exhibits important potential applications in the diagnosis of $\mathrm{H}_{2} \mathrm{O}_{2}$-related diseases.

\section{Materials and Methods}

\subsection{Materials and Instruments}

All chemicals used were of reagent grade or purchased as high-grade commercial products and used without further purification. Solvents used were purified via standard methods. ${ }^{1} \mathrm{H}$ NMR spectra were recorded on a Bruker AVANCE III $400 \mathrm{MHz}$ spectrometer. Mass spectrometric data were performed on an LTQ Orbitrap XL spectrometer. The highperformance liquid chromatography (HPLC) experiment was recorded on an Agilent 1260 LC system (USA). Fluorescent spectra were achieved with an F7000 fluorescence spectrophotometer. The UV-vis spectra were recorded on a TU $1900 \mathrm{UV}$-vis spectrometer. The Dulbecco's modified Eagle's medium (DMEM) that was added with $10 \%$ fetal bovine serum (FBS), was used to culture all the cell lines. The OD values of the CCK8 assay were measured by BIO-RAD xMark microplate spectrophotometer. Confocal fluorescence imaging was performed on an OLYMPUS FV1000 confocal microscopy.

\subsection{Synthesis of Compound $\mathbf{1}$}

Compound 1 was synthesized according to a previously published article [41]. 2,4dihydroxybenzaldehyde $(1.38 \mathrm{~g}, 10.0 \mathrm{mmol})$ and diethyl malonate $(1.92 \mathrm{~g}, 12.0 \mathrm{mmol})$ were 
dissolved in anhydrous $\mathrm{EtOH}$, and then an appropriate amount of piperidine was added. The reaction mixture was refluxed for $12 \mathrm{~h}$ and then cooled. The precipitate was collected and washed with cold EtOH to obtain the yellow compound $1(1.87 \mathrm{~g})$ with a yield of $80 \%$. ${ }^{1} \mathrm{H}$ NMR $\left(400 \mathrm{MHz}\right.$, DMSO- $\left.d_{6}\right) \delta 11.07(\mathrm{~s}, 1 \mathrm{H}), 8.65(\mathrm{~s}, 1 \mathrm{H}), 7.73(\mathrm{~d}, J=8.6 \mathrm{~Hz}, 1 \mathrm{H}), 6.82(\mathrm{dd}$, $J=8.6,2.1 \mathrm{~Hz}, 1 \mathrm{H}), 6.70(\mathrm{~d}, J=1.9 \mathrm{~Hz}, 1 \mathrm{H}), 4.26(\mathrm{q}, J=7.1 \mathrm{~Hz}, 2 \mathrm{H}), 1.30(\mathrm{t}, J=7.1 \mathrm{~Hz}, 3 \mathrm{H})$.

\subsection{Synthesis of Compound $\mathbf{C M}$}

Compound $1(0.41 \mathrm{~g}, 2.0 \mathrm{mmol})$ was dissolved in ethanol, then $\mathrm{N}$-(2-methylamino)morpholine $(0.31 \mathrm{~g}, 2.4 \mathrm{mmol})$ and triethylamine $(2.4 \mathrm{mmol})$ were added. The mixture was heated to reflux for $8 \mathrm{~h}$ and cooled after the reaction was complete. Then the precipitate was filtered, and the filtrate was extracted with dichloromethane and water. The organic layers were combined and dried over anhydrous sodium sulfate and column chromatography $\left(\mathrm{CH}_{2} \mathrm{Cl}_{2}: \mathrm{CH}_{3} \mathrm{OH}=100: 1\right)$ to obtain compound $\mathrm{CM}(0.417 \mathrm{~g}$, yield $65.4 \%) .{ }^{1} \mathrm{H}$ NMR $\left(400 \mathrm{MHz}, \mathrm{DMSO}-d_{6}\right) \delta 11.03(\mathrm{~s}, 1 \mathrm{H}), 8.85(\mathrm{t}, J=5.3 \mathrm{~Hz}, 1 \mathrm{H}), 8.79(\mathrm{~s}, 1 \mathrm{H}), 7.82(\mathrm{~d}, J=8.6 \mathrm{~Hz}$, $1 \mathrm{H}), 6.88(\mathrm{dd}, J=8.6,2.2 \mathrm{~Hz}, 1 \mathrm{H}), 6.84-6.73(\mathrm{~m}, 1 \mathrm{H}), 3.74-3.54(\mathrm{~m}, 4 \mathrm{H}), 3.43(\mathrm{q}, J=6.2 \mathrm{~Hz}$, $2 \mathrm{H}), 2.48(\mathrm{~d}, J=6.4 \mathrm{~Hz}, 2 \mathrm{H}), 2.42(\mathrm{~s}, 4 \mathrm{H})$.

\subsection{Synthesis of Compound $\mathbf{C M B}$}

$\mathrm{CM}(0.32 \mathrm{~g}, 1.0 \mathrm{mmol})$ and $\mathrm{K}_{2} \mathrm{CO}_{3}(0.42 \mathrm{~g}, 3.0 \mathrm{mmol})$ were dissolved in $5 \mathrm{~mL} \mathrm{CH}_{3} \mathrm{CN}$ and then 2-(4-(bromomethyl)phenyl)-4,4,5,5-tetramethyl-1,3,2-dioxaborolane (0.42 g, $1.4 \mathrm{mmol}$ ) was also added to the mixture. The reaction mixture was heated at $80{ }^{\circ} \mathrm{C}$ for $24 \mathrm{~h}$ and cooled to room temperature. Then, the mixture was diluted with $\mathrm{CH}_{2} \mathrm{Cl}_{2}$ and water and the aqueous layer was extracted with $\mathrm{CH}_{2} \mathrm{Cl}_{2}$. The combined organic phase was washed with water and dried with anhydrous sodium sulfate, then purified by column chromatography $\left(\mathrm{CH}_{2} \mathrm{Cl}_{2}: \mathrm{CH}_{3} \mathrm{OH}=100: 1\right)$ to obtain a white solid $(0.25 \mathrm{~g})$ with the yield of $46.7 \% .{ }^{1} \mathrm{H}$ NMR $\left(400 \mathrm{MHz}, \mathrm{DMSO}-d_{6}\right) \delta 8.85(\mathrm{~d}, J=3.8 \mathrm{~Hz}, 2 \mathrm{H}), 7.92(\mathrm{~d}, J=8.7 \mathrm{~Hz}, 1 \mathrm{H})$, $7.72(\mathrm{~d}, J=7.8 \mathrm{~Hz}, 2 \mathrm{H}), 7.49(\mathrm{~d}, J=7.8 \mathrm{~Hz}, 2 \mathrm{H}), 7.18(\mathrm{~d}, J=2.1 \mathrm{~Hz}, 1 \mathrm{H}), 7.12(\mathrm{dd}, J=8.7$, $2.2 \mathrm{~Hz}, 1 \mathrm{H}), 5.32(\mathrm{~s}, 2 \mathrm{H}), 3.59(\mathrm{t}, J=4.6 \mathrm{~Hz}, 4 \mathrm{H}), 3.44(\mathrm{q}, J=6.1 \mathrm{~Hz}, 2 \mathrm{H}), 2.47(\mathrm{~d}, J=6.4 \mathrm{~Hz}$, $2 \mathrm{H}), 2.42(\mathrm{~s}, 4 \mathrm{H}), 1.30(\mathrm{~s}, 12 \mathrm{H})$.

\subsection{Preparation of Related Species and Configuration of Solutions}

Probe $\mathrm{CMB}$ was dissolved with DMSO to prepare stock solutions. Adding $4 \mu \mathrm{L}$ probe stock solution into $2 \mathrm{~mL}$ acetonitrile/phosphate buffer $(1: 9 v / v, 10 \mathrm{mM}, \mathrm{pH} 7.4)$ with the final concentration of probe as $2 \mu \mathrm{M}$ for fluorescent spectra test. $\mathrm{H}_{2} \mathrm{O}_{2}, \mathrm{ClO}^{-}, \mathrm{TBHP}, \mathrm{NO}_{2}{ }^{-}$, and $\mathrm{NO}_{3}{ }^{-}$obtained from commercial sources were diluted or dissolved in water. Other reactive oxygen species are prepared according to the literature $[42,43]$. $\mathrm{ONOO}^{-}$was prepared by mixing pre-cooled $0.6 \mathrm{M} \mathrm{NaNO}_{2}, 0.6 \mathrm{M} \mathrm{HCl}$, and $0.7 \mathrm{M} \mathrm{H}_{2} \mathrm{O}_{2}$ into $1.5 \mathrm{M} \mathrm{NaOH}$ at $0{ }^{\circ} \mathrm{C}$. Manganese dioxide was then added to the solution to eliminate the residual $\mathrm{H}_{2} \mathrm{O}_{2}$ and was removed by filtration. Its concentration was estimated by its extinction coefficient of $1670 \mathrm{M}^{-1} \mathrm{~cm}^{-1}$ at $302 \mathrm{~nm}$. A singlet oxygen solution was prepared by the reaction of $\mathrm{H}_{2} \mathrm{O}_{2}$ and sodium hypochlorite solution. Hydroxyl radical was generated by the Fenton reaction and can be acquired by adding $\mathrm{Fe}^{2+}$ to $\mathrm{H}_{2} \mathrm{O}_{2}$.

\subsection{Measurement of Detection Limit}

The detection limit was obtained from the fluorescence titration curve and was calculated according to the following equations [44]:

$$
\text { Detection limit }=3 \sigma / \mathrm{k}
$$

Here $\sigma$ represents the deviation of blank and $\mathrm{k}$ is the slope of the linear regression equation.

\subsection{Cell Culture and Cytotoxicity Assay}

The Michigan Cancer Foundation-7 (MCF-7) cells were allowed to culture for $24 \mathrm{~h}$ at $37^{\circ} \mathrm{C}$ with medium supplemented with $10 \%$ fetal bovine serum (FBS) in a $5 \% \mathrm{CO}_{2}$ 
humidified incubator. Cells were seeded in 96-well microplates for $24 \mathrm{~h}$ and then cultured in medium with $0,1,2,5,10$, and $20 \mu \mathrm{M}$ of probe CMB for $24 \mathrm{~h}$. Cells in culture medium without probe were used as the control. The solution of CCK-8 reagent was added to each well and the plates were incubated for another $1 \mathrm{~h}$. The medium was then removed carefully, and the absorbance of solutions was determined on a microplate reader at $450 \mathrm{~nm}$.

\subsection{Cell Imaging}

The MCF-7 cells were treated with different concentrations of $\mathrm{H}_{2} \mathrm{O}_{2}(0 \mu \mathrm{M}, 10 \mu \mathrm{M}$, $20 \mu \mathrm{M}, 30 \mu \mathrm{M}, 40 \mu \mathrm{M}, 50 \mu \mathrm{M})$ and then incubated with CMB $(2 \mu \mathrm{M})$ at $37^{\circ} \mathrm{C}$ to detect exogenous $\mathrm{H}_{2} \mathrm{O}_{2}$. In addition, MCF-7 cells were stimulated with rotenone $(2 \mu \mathrm{M})$ at $37^{\circ} \mathrm{C}$ to produce endogenous $\mathrm{H}_{2} \mathrm{O}_{2}$, and then treated with $\mathrm{CMB}(2 \mu \mathrm{M})$. Then, another group of MCF-7 cells was first stimulated with rotenone $(2 \mu \mathrm{M})$, incubated with NAC $(1 \mathrm{mM})$ to eliminate the endogenous $\mathrm{H}_{2} \mathrm{O}_{2}$, and treated with $\mathrm{CMB}(2 \mu \mathrm{M})$ at $37{ }^{\circ} \mathrm{C}$. The cells were washed three times with PBS after incubation, and then imaged on a confocal laser microscope with a $60 \times$ objective lens.

\subsection{Zebrafish Imaging}

Zebrafish embryos were maintained at $28.5^{\circ} \mathrm{C}$. First, the zebrafish were only incubated with CMB $(2 \mu \mathrm{M})$ as the control group. Another group of zebrafish was stimulated with rotenone $(2 \mu \mathrm{M})$, and then treated with $\mathbf{C M B}(2 \mu \mathrm{M})$. Then the last group of zebrafish was stimulated with rotenone $(2 \mu \mathrm{M})$, incubated with NAC $(1 \mathrm{mM})$ to eliminate the endogenous $\mathrm{H}_{2} \mathrm{O}_{2}$, and treated with $\mathrm{CMB}(2 \mu \mathrm{M})$. The zebrafish were washed three times with PBS after incubation and imaged on a confocal laser microscope with a $4 \times$ objective lens.

Supplementary Materials: The following are available online, Figure S1: The 1H NMR of compound 1 in DMSO-d6 solution, Figure S2: The 1H NMR of compound CM in DMSO-d6 solution, Figure S3: The 1H NMR of compound CMB in DMSO-d6 solution, Figure S4: The HRMS of compound CMB, Table S1: Properties of the previously developed fluorescent $\mathrm{H} 2 \mathrm{O} 2$ probes and the probe $\mathrm{CMB}$, Figure S5: The confocal z-scan images of zebrafish treated with probe and $\mathrm{H} 2 \mathrm{O} 2$. Zebrafish were incubated with $\mathrm{H} 2 \mathrm{O} 2$ and then stained with $\mathbf{C M B}(2 \mu \mathrm{M})$. The excitation wavelength was 405 $\mathrm{nm}$ and the emission was collected at 420 to $520 \mathrm{~nm}$.

Author Contributions: Conceptualization, Y.J.; methodology, Y.J. and C.D.; formal analysis, Y.Z. and C.M.; writing—original draft, Y.Z. and Y.J.; writing—review and editing, Y.Z., Y.J., and C.D.; project administration, Y.J.; supervision, C.D. All authors have read and agreed to the published version of the manuscript.

Funding: This research was funded by the National Natural Science Foundation of China (21977015 and 21820102001), and the Fundamental Research Funds for the Central Universities (DUT20LK12).

Acknowledgments: We acknowledge Jiqiu Yin (from Dalian Medical University) for her assistance in cytotoxicity experiments.

Conflicts of Interest: The authors declare no conflict of interest.

Sample Availability: Samples of the compounds are not available from the authors.

\section{References}

1. Schieber, M.; Chandel, N.S. ROS function in redox signaling and oxidative stress. Curr. Biol. 2014, 24, R453-R462. [CrossRef]

2. Fang, Y.; Dehaen, W. Fluorescent Probes for Selective Recognition of Hypobromous Acid: Achievements and Future Perspectives. Molecules 2021, 26, 363. [CrossRef]

3. Sena, L.A.; Chandel, N.S. Physiological roles of mitochondrial reactive oxygen species. Mol. Cell 2012, 48, 158-167. [CrossRef]

4. Dixon, S.J.; Stockwell, B.R. The role of iron and reactive oxygen species in cell death. Nat. Chem. Biol. 2014, 10, 9-17. [CrossRef]

5. Kwon, N.; Kim, D.; Swamy, K.M.K.; Yoon, J. Metal-coordinated fluorescent and luminescent probes for reactive oxygen species (ROS) and reactive nitrogen species (RNS). Coord. Chem. Rev. 2021, 427, 213581. [CrossRef]

6. Ray, P.D.; Huang, B.-W.; Tsuji, Y. Reactive oxygen species (ROS) homeostasis and redox regulation in cellular signaling. Cell. Signal. 2012, 24, 981-990. [CrossRef]

7. D'Autréaux, B.; Toledano, M.B. ROS as signalling molecules: Mechanisms that generate specificity in ROS homeostasis. Nat. Rev. Mol. Cell Biol. 2007, 8, 813-824. [CrossRef] [PubMed] 
8. Kamata, H.; Honda, S.; Maeda, S.; Chang, L.; Hirata, H.; Karin, M. Reactive oxygen species promote TNFalpha-induced death and sustained JNK activation by inhibiting MAP kinase phosphatases. Cell 2005, 120, 649-661. [CrossRef]

9. Yan, K.C.; Sedgwick, A.C.; Zang, Y.; Chen, G.R.; He, X.P.; Li, J.; Yoon, J.; James, T.D. Sensors, Imaging Agents, and Theranostics to Help Understand and Treat Reactive Oxygen Species Related Diseases. Small Methods 2019, 3, 1900013. [CrossRef]

10. Ye, S.; Hu, J.J.; Yang, D. Tandem Payne/Dakin Reaction: A New Strategy for Hydrogen Peroxide Detection and Molecular Imaging. Angew. Chem. Int. Ed. 2018, 57, 10173-10177. [CrossRef]

11. Narayanaswamy, N.; Narra, S.; Nair, R.R.; Saini, D.K.; Kondaiah, P.; Govindaraju, T. Stimuli-responsive colorimetric and NIR fluorescence combination probe for selective reporting of cellular hydrogen peroxide. Chem. Sci. 2016, 7, 2832-2841. [CrossRef] [PubMed]

12. Gorrini, C.; Harris, I.S.; Mak, T.W. Modulation of oxidative stress as an anticancer strategy. Nat. Rev. Drug. Discov. 2013, 12, 931-947. [CrossRef] [PubMed]

13. Singh, A.; Kukreti, R.; Saso, L.; Kukreti, S. Oxidative Stress: A Key Modulator in Neurodegenerative Diseases. Molecules 2019, 24, 1583. [CrossRef]

14. Miyata, Y.; Mukae, Y.; Harada, J.; Matsuda, T.; Mitsunari, K.; Matsuo, T.; Ohba, K.; Sakai, H. Pathological and Pharmacological Roles of Mitochondrial Reactive Oxygen Species in Malignant Neoplasms: Therapies Involving Chemical Compounds, Natural Products, and Photosensitizers. Molecules 2020, 25, 5252. [CrossRef]

15. Zhang, Y.; Dai, M.; Yuan, Z. Methods for the detection of reactive oxygen species. Anal. Methods 2018, 10, 4625-4638. [CrossRef]

16. Zhu, Y.; Ma, Y.; Liu, Y.; Liu, Z.; Ma, S.; Xing, M.; Cao, D.; Lin, W. Fluorescence response of a fluorescein derivative for hypochlorite ion and its application for biological imaging in wounded zebrafish and living mice. Sens. Actuators B Chem. 2021, 327, 128848. [CrossRef]

17. Singh, H.; Tiwari, K.; Tiwari, R.; Pramanik, S.K.; Das, A. Small Molecule as Fluorescent Probes for Monitoring Intracellular Enzymatic Transformations. Chem. Rev. 2019, 119, 11718-11760. [CrossRef] [PubMed]

18. Kim, S.J.; Yoon, J.W.; Yoon, S.A.; Lee, M.H. Ratiometric Fluorescence Assay for Nitroreductase Activity: Locked-Flavylium Fluorophore as a NTR-Sensitive Molecular Probe. Molecules 2021, 26, 1088. [CrossRef] [PubMed]

19. Wu, L.; Qu, X. Cancer biomarker detection: Recent achievements and challenges. Chem. Soc. Rev. 2015, 44, 2963-2997. [CrossRef]

20. Wei, X.; Hao, M.; Hu, X.; Song, Z.; Wang, Y.; Sun, R.; Zhang, J.; Yan, M.; Ding, B.; Yu, J. A near-infrared fluorescent probe with large stokes shift for accurate detection of $\beta$-glucuronidase in living cells and mouse models. Sens. Actuators B Chem. 2021, 326, 128849. [CrossRef]

21. Obara, R.; Kamiya, M.; Tanaka, Y.; Abe, A.; Kojima, R.; Kawaguchi, T.; Sugawara, M.; Takahashi, A.; Noda, T.; Urano, Y. $\gamma$-Glutamyltranspeptidase (GGT)-Activatable Fluorescence Probe for Durable Tumor Imaging. Angew. Chem. Int. Ed. 2021, 60, 2125-2129. [CrossRef]

22. Choi, N.E.; Lee, J.Y.; Park, E.C.; Lee, J.H.; Lee, J. Recent Advances in Organelle-Targeted Fluorescent Probes. Molecules 2021, 26, 217. [CrossRef]

23. Zhou, Z.; Li, Y.; Su, W.; Gu, B.; Xu, H.; Wu, C.; Yin, P.; Li, H.; Zhang, Y. A dual-signal colorimetric and near-infrared fluorescence probe for the detection of exogenous and endogenous hydrogen peroxide in living cells. Sens. Actuators B Chem. 2019, 280, 120-128. [CrossRef]

24. Dong, B.; Song, X.; Kong, X.; Wang, C.; Tang, Y.; Liu, Y.; Lin, W. Simultaneous Near-Infrared and Two-Photon In Vivo Imaging of $\mathrm{H}_{2} \mathrm{O}_{2}$ Using a Ratiometric Fluorescent Probe based on the Unique Oxidative Rearrangement of Oxonium. Adv. Mater. 2016, 28, 8755-8759. [CrossRef] [PubMed]

25. Ren, M.; Deng, B.; Zhou, K.; Kong, X.; Wang, J.Y.; Lin, W. Single Fluorescent Probe for Dual-Imaging Viscosity and $\mathrm{H}_{2} \mathrm{O}_{2}$ in Mitochondria with Different Fluorescence Signals in Living Cells. Anal. Chem. 2017, 89, 552-555. [CrossRef] [PubMed]

26. Li, N.; Huang, J.; Wang, Q.; Gu, Y.; Wang, P. A reaction based one- and two-photon fluorescent probe for selective imaging $\mathrm{H}_{2} \mathrm{O}_{2}$ in living cells and tissues. Sens. Actuators B Chem. 2018, 254, 411-416. [CrossRef]

27. Song, X.; Bai, S.; He, N.; Wang, R.; Xing, Y.; Lv, C.; Yu, F. Real-Time Evaluation of Hydrogen Peroxide Injuries in Pulmonary Fibrosis Mice Models with a Mitochondria-Targeted Near-Infrared Fluorescent Probe. ACS Sens. 2021, 6, 1228-1239. [CrossRef] [PubMed]

28. Lippert, A.R.; Bittner, G.C.V.; Chang, C.J. Boronate Oxidation as a Bioorthogonal Reaction Approach for Studying the Chemistry of Hydrogen Peroxide in Living Systems. Acc. Chem. Res. 2011, 44, 793-804. [CrossRef]

29. Ni, Y.; Liu, H.; Dai, D.; Mu, X.; Xu, J.; Shao, S. Chromogenic, Fluorescent, and Redox Sensors for Multichannel Imaging and Detection of Hydrogen Peroxide in Living Cell Systems. Anal. Chem. 2018, 90, 10152-10158. [CrossRef]

30. Liu, X.; He, L.; Yang, L.; Geng, Y.; Yang, L.; Song, X. Iminocoumarin-based fluorescence probe for intracellular $\mathrm{H}_{2} \mathrm{O}_{2}$ detection with a red emission and a large Stokes shift. Sens. Actuators B Chem. 2018, 259, 803-808. [CrossRef]

31. Cao, D.; Liu, Z.; Verwilst, P.; Koo, S.; Jangjili, P.; Kim, J.S.; Lin, W. Coumarin-Based Small-Molecule Fluorescent Chemosensors Chem. Rev. 2019, 119, 10403-10519. [CrossRef] [PubMed]

32. Dsouza, R.N.; Pischel, U.; Nau, W.M. Fluorescent dyes and their supramolecular host/guest complexes with macrocycles in aqueous solution. Chem. Rev. 2011, 111, 7941-7980. [CrossRef] [PubMed]

33. Liu, Y.; Jiao, C.; Lu, W.; Zhang, P.; Wang, Y. Research progress in the development of organic small molecule fluorescent probes for detecting $\mathrm{H}_{2} \mathrm{O}_{2}$. RSC Adv. 2019, 9, 18027-18041. [CrossRef] 
34. Zheng, D.-J.; Yang, Y.-S.; Zhu, H.-L. Recent progress in the development of small-molecule fluorescent probes for the detection of hydrogen peroxide. Trac Trends Anal. Chem. 2019, 118, 625-651. [CrossRef]

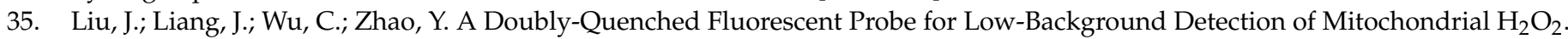
Anal. Chem. 2019, 91, 6902-6909. [CrossRef] [PubMed]

36. Kuang, Y.; Balakrishnan, K.; Gandhi, V.; Peng, X. Hydrogen peroxide inducible DNA cross-linking agents: Targeted anticancer prodrugs. J. Am. Chem. Soc. 2011, 133, 19278-19281. [CrossRef]

37. Liu, X.; Feng, Q.; Bachhuka, A.; Vasilev, K. Surface modification by allylamine plasma polymerization promotes osteogenic differentiation of human adipose-derived stem cells. ACS Appl. Mater. Interfaces 2014, 6, 9733-9741. [CrossRef]

38. Zhang, J.; Shi, L.; Li, Z.; Li, D.; Tian, X.; Zhang, C. Near-infrared fluorescence probe for hydrogen peroxide detection: Design, synthesis, and application in living systems. Analyst 2019, 144, 3643-3648. [CrossRef]

39. Li, H.; Xin, C.; Zhang, G.; Han, X.; Qin, W.; Zhang, C.-W.; Yu, C.; Jing, S.; Li, L.; Huang, W. A mitochondria-targeted two-photon fluorogenic probe for the dual-imaging of viscosity and $\mathrm{H}_{2} \mathrm{O}_{2}$ levels in Parkinson's disease models. J. Mater. Chem. B 2019, 7 , 4243-4251. [CrossRef]

40. Gong, Y.J.; Feng, D.D.; Liu, W.N.; Fang, J.K.; Feng, S. A self-immolative near-infrared probe based on hemi-benzothiazolecyanine for visualizing hydrogen peroxide in living cells and mice. Dye. Pigment. 2021, 186, 108954. [CrossRef]

41. Li, H.; Wang, X.; Xu, G.; Zeng, L.; Cheng, K.; Gao, P.; Sun, Q.; Liao, W.; Zhang, J. Synthesis and biological evaluation of a novel class of coumarin derivatives. Bioorg Med Chem Lett 2014, 24, 5274-5278. [CrossRef] [PubMed]

42. Li, X.; Tao, R.R.; Hong, L.J.; Cheng, J.; Jiang, Q.; Lu, Y.M.; Liao, M.H.; Ye, W.F.; Lu, N.N.; Han, F.; et al. Visualizing peroxynitrite fluxes in endothelial cells reveals the dynamic progression of brain vascular injury. J. Am. Chem. Soc. 2015, 137, 12296-12303. [CrossRef] [PubMed]

43. Zhang, H.; Tian, D.; Zheng, Y.; Dai, F.; Zhou, B. Designing an ESIPT-based fluorescent probe for imaging of hydrogen peroxide during the ferroptosis process. Spectrochim. Acta Part A Mol. Biomol. Spectrosc. 2021, 248, 119264. [CrossRef] [PubMed]

44. Li, H.; Yao, Q.; Fan, J.; Du, J.; Wang, J.; Peng, X. A two-photon NIR-to-NIR fluorescent probe for imaging hydrogen peroxide in living cells. Biosens. Bioelectron. 2017, 94, 536-543. [CrossRef] 